\title{
Spectrum Launch: Slack time, job searches, pandemic mentoring
}

\section{BY ANGIE VOYLES ASKHAM}

11 NOVEMBER 2021

Hello and welcome to the first edition of Spectrum Launch, a newsletter about how to navigate the uncharted waters of autism research in the early stages of your career.

The goal of this newsletter is to provide guidance and resources for early-career autism researchers who are beginning graduate school, completing a dissertation, landing an academic job or starting a research group. We plan to interview people who have overcome career challenges and to call out bumps along the 'academic career' road. We also want to serve up practical information about essential tools, techniques and learning opportunities.

Because one of the most important resources for early-career researchers is community, we want to make this a place where we can develop that, too. So: Any burning questions for fellow researchers, things you wish you knew when you were starting out, or suggestions for how to make this newsletter as useful as possible? Send them to angie@spectrumnews.org.

\section{Tech support:}

One of the big milestones in a research career is starting a lab. But life as a new principal investigator ( $\mathrm{PI}$ ) can be challenging — and lonely.

"You suddenly have to figure out how to manage budgets, hire people, push research forward, delegate things to others and navigate the university bureaucracy," says Chiara Manzini, associate professor of neuroscience and cell biology at the Rutgers Robert Wood Johnson Medical School in New Brunswick, New Jersey, who started her own lab almost 10 years ago.

Enter the New PI Slack group. The community — founded in 2016 by cell biologist Prachee Avasthi, now associate professor at Dartmouth University in Hanover, New Hampshire - is open to researchers of all disciplines who have recently set up their own lab. 


\section{Spectrum | Autism Research News}

https://www.spectrumnews.org

Across various 'channels,' novice Pls can consult one another on a host of topics, including how to apply for grants, deal with personnel conflicts and manage childcare. Some channels focus on specific geographic regions or areas of research. There isn't a dedicated channel for autism research, Manzini says, but she found support in the 'neuroscience' channel.

Because members agree to keep conversations confidential ("what's discussed in the Slack stays in the Slack" is one of the group's mottos), new Pls feel comfortable asking questions they might otherwise be afraid to raise, Manzini says.

The group also celebrates fellow members' achievements, such as successful grant applications and even departures to the 'Mid-Career PI Slack' community. (For postdoctoral researchers, there's also a 'Future PI Slack' option.)

In April, Alexander Chubykin, who studies circuit plasticity and visual perception at Purdue University in West Lafayette, Indiana, was awarded tenure and promoted to associate professor meaning he's no longer eligible for the New PI Slack group.

Such announcements are typically met with "hundreds of crying faces," as people say goodbye, says Manzini, who, like Chubykin, has now graduated to the mid-career group.

Chubykin says he had plenty of support from his department when he was starting out, but the New PI Slack group offered a way to connect with peers who were often more up to date on the latest techniques and requirements in his specific area of study.

"It's helpful to know that other people are going through the same challenges," Chubykin says.

\section{Jobs and funds:}

- If you're looking to learn more about money and funding in academia, this Twitter thread is a helpful guide.

- The Autism Science Foundation, which offers multiple funding opportunities for autism researchers, has a new fellowship for students who have a bachelor's degree and want to gain research experience by working full-time in a lab. The deadline for this and other Autism Science Foundation awards is 7 December.

- The Psych Job Search webpage boasts a number of job listings - from postdoctoral to tenure-track positions. Noah Sasson shared this site on Twitter, along with the tip that those seeking a postdoctoral position should also try reaching out to Pls in their area. "Fortune favors the brave ... and the well-funded," he said.

Also, my general advice: contact Pls in your area to see if they have any available 


\section{Spectrum | Autism Research News}

https://www.spectrumnews.org

positions. Fortune favors the brave... and the well-funded.

— Noah Sasson (@Noahsasson) August 18, 2021

\section{Recommended reads:}

- The International Society for Autism Research released a special edition of their Student and Trainee Committee newsletter earlier this month, featuring advice from experts in the field.

- Applying to grad school? This Twitter thread has some tips for improving your application and setting yourself up for success from day one.

- Early- and late-career researchers alike can find words of guidance in this review on the Ph.D.-student-supervisor relationship.

- The pandemic may have long-term effects on scientific mentoring - some negative, but many positive. Researchers discuss those changes on Nature's podcast series, "Working Scientist"

- Researchers entering the tenure-track job market need to prepare a 'chalk talk.' But what does that even mean? Leslie Vosshall, professor of neurogenetics at Rockefeller University in New York City, has some tips:

It's tenure-track biomedical academic search season and "chalk talks" are right around the corner. Chalk talks are not something we "teach" our trainees and most postdocs are unprepared for them as a result.

Here are my Chalk Talk Pro Tips:https://t.co/nueGEsD3V7

— Leslie Vosshall PhD (@leslievosshall) October 26, 2021

- And this paper addresses some of the myths and facts behind the mysterious process of getting an academic faculty position in neuroscience.

- Although, if you're anything like this author, serving on a hiring committee may change your mind about wanting to become a professor.

- Researchers who contribute to a study early in their career can end up as 'ghost authors' on the final paper. Read one author's plea for senior scientists to properly credit earlycareer researchers for their work.

- Lastly, reporters chronicled multiple years in the lives of two UK-based researchers trying to get their labs running and funded - and all of their ups and downs - in a multi-part 


\section{Spectrum | Autism Research News}

https://www.spectrumnews.org

feature for Nature.

Cite this article: https://doi.org/10.53053/LCZE5695 